\title{
Are Bordetella bronchiseptica Siphoviruses (Genus Vojvodinavirus) Appropriate for Phage Therapy-Bacterial Allies or Foes?
}

\author{
Aleksandra Petrovic Fabijan ${ }^{1,2, *}$, Verica Aleksic Sabo ${ }^{1}$, Damir Gavric ${ }^{1}$, Zsolt Doffkay ${ }^{3}$, Gábor Rakhely ${ }^{3}$ and \\ Petar Knezevic 1,*
}

1 Department of Biology and Ecology, Faculty of Sciences, University of Novi Sad, Trg Dositeja Obradovica 3, 21000 Novi Sad, Serbia; verica.aleksic@dbe.uns.ac.rs (V.A.S.); damir.gavric@dbe.uns.ac.rs (D.G.)

2 Centre for Infectious Diseases and Microbiology, Westmead Institute for Medical Research, 176 Hawkesbury Road, Westmead, NSW 2145, Australia

3 Department of Biotechnology, University of Szeged, Temesvari krt. 62, H-6726 Szeged, Hungary; zsolt.doffkay@bio.u-szeged.hu (Z.D.); rakhely@brc.hu (G.R.)

* Correspondence: aleksandra.petrovicfabijan@sydney.edu.au (A.P.F.); petar.knezevic@dbe.uns.ac.rs (P.K.); Tel.: +61-286273441 (A.P.F.); +381-214852681 (P.K.)

Citation: Petrovic Fabijan, A.; Aleksic Sabo, V.; Gavric, D.; Doffkay, Z.; Rakhely, G.; Knezevic, P. Are Bordetella bronchiseptica Siphoviruses (Genus Vojvodinavirus) Appropriate for Phage Therapy-Bacterial Allies or Foes? Viruses 2021, 13, 1732. https://doi.org/10.3390/v13091732

Academic Editor: Dann Turner

Received: 31 July 2021

Accepted: 27 August 2021

Published: 31 August 2021

Publisher's Note: MDPI stays neutral with regard to jurisdictional claims in published maps and institutional affiliations.

Copyright: (c) 2021 by the authors. Licensee MDPI, Basel, Switzerland. This article is an open access article distributed under the terms and conditions of the Creative Commons Attribution (CC BY) license (https:/ / creativecommons.org/licenses/by/ $4.0 /)$.

\begin{abstract}
Bordetella bronchiseptica is a respiratory animal pathogen that shows growing resistance to commonly used antibiotics, which has necessitated the examination of new antimicrobials, including bacteriophages. In this study, we examined the previously isolated and partially characterized B. bronchiseptica siphoviruses of the genus Vojvodinavirus (LK3, CN1, CN2, FP1 and MW2) for their ability to inhibit bacterial growth and biofilm, and we examined other therapeutically important properties through genomic analysis and lysogeny experiments. The phages inhibited bacterial growth at a low multiplicity of infection (MOI $=0.001$ ) of up to $85 \%$ and at MOI $=1$ for $>99 \%$. Similarly, depending on the phages and MOIs, biofilm formation inhibition ranged from 65 to $95 \%$. The removal of biofilm by the phages was less efficient but still considerably high (40-75\%). Complete genomic sequencing of Bordetella phage LK3 (59,831 bp; G + C 64.01\%; 79 ORFs) showed integrase and repressor protein presence, indicating phage potential to lysogenize bacteria. Lysogeny experiments confirmed the presence of phage DNA in bacterial DNA upon infection using PCR, which showed that the LK3 phage forms more or less stable lysogens depending on the bacterial host. Bacterial infection with the LK3 phage enhanced biofilm production, sheep blood hemolysis, flagellar motility, and beta-lactam resistance. The examined phages showed considerable anti-B. bronchiseptica activity, but they are inappropriate for therapy because of their temperate nature and lysogenic conversion of the host bacterium.
\end{abstract}

Keywords: Bordetella bronchiseptica; Vojvodinavirus; growth inhibition; biofilm; lysogeny

\section{Introduction}

Bordetella bronchiseptica is primarily a respiratory pathogen of domestic, wild, and laboratory animals [1] and is considered to be the evolutionary progenitor of all species of the Bordetella genus, including the well-known human pathogens B. pertussis and B. parapertussis [2]. The prevalence of $B$. bronchiseptica infection is the highest in dogs, cats, swine, rabbits and Guinea pigs, while bordetellosis is rarely documented in horses, monkeys, foxes, rats, opossum, birds or other animals [3-5]. Infections caused by B. bronchiseptica can manifest from almost asymptomatic to severe purulent pneumonia [6]. Moreover, B. bronchiseptica is one of the main causative agents of a few highly contagious and economically significant diseases, including kennel cough, atrophic rhinitis and upper respiratory tract disease (snuffles) [7-9]. Although it is generally considered a zoonotic agent, B. bronchiseptica rarely causes infection in humans, with the exception of immunocompromised individuals [10].

The vaccine for B. bronchiseptica, commonly used since 1970s, is unreliable as it does not provide long-term immunity [11,12]. In addition, the increased degree of resistance to $B$. bronchiseptica isolates against commonly used antibiotics, including $\beta$-lactams, macrolides 
and tetracyclines, has become a serious concern [13-15]. In the last few years, the use of bacteriophages in the treatment of bacterial infections has gained the attention of the scientific community [16-19]. Accordingly, bacteriophage therapy offers an alternative or complementary strategy to conventional antimicrobials for more efficient $B$. bronchiseptica control.

Only several B. bronchiseptica-specific phages have been isolated and characterized. A few related B. bronchispetica phages from the Podoviridae family have been examined in detail, and their genomic analysis indicated involvement in host lysogenic conversion [20]. Recently, phages from the Myoviridae and Podoviridae families that infect B. bronchiseptica were described without showing evidence of lysogeny formation [21,22]. In addition, we reported the first isolation of several phages from the Siphoviridae family that are specific to B. bronchiseptica [23], but these were not characterized in detail. According to the International Committee for Taxonomy of Viruses (ICTV) report (2019), these phages are classified under the genus Vojvodinavirus [24]. They comprise four species-Bordetella virus CN1 (with strains Bordetella phage CN1 and Bordetella phage LK3), Bordetella virus CN2, Bordetella virus FP1 and Bordetella virus MW2. The partial genomic sequence of virus CN1 showed similarity with Pseudomonas phages from the genus Yuavirus (40\%), while transmission electron microscopy, efficacy of plating and RFLP patterns demonstrated high relatedness between examined siphoviruses [23]. Building on this work, we aimed to determine if $B$. bronchiseptica-specific siphoviruses were appropriate for phage therapy. We examined their potential to inhibit bacterial growth and biofilm formation and reduce existing B. bronchiseptica biofilm. In addition, we used genomic analysis and conducted lysogeny formation experiments to examine bacterial phenotypic properties after infection with these phages.

\section{Materials and Methods}

\subsection{Bacterial Strains}

For estimation of phage lytic efficacy on biofilm formation and eradication of already formed biofilm, the B. bronchiseptica ATCC 10580 strain was used. To examine lysogeny formation, in addition to the reference strain, BbChiot and Bbr3416 animal strains were used $[25,26]$. All bacteria were stored in Luria Bertani broth (LB) containing glycerol $(10 \% v / v)$ at $-70{ }^{\circ} \mathrm{C}$. For the experiments, they were inoculated in LB and incubated overnight at $37^{\circ} \mathrm{C}$, if not stated otherwise.

\subsection{Phages}

Five B. bronchiseptica-specific siphoviruses (LK3, CN1, CN2, MW2 and FP1) previously isolated from environmental samples and partially characterized, were examined in this study [23]. All phages were propagated, precipitated in 10\% PEG6000 and $1 \mathrm{M} \mathrm{NaCl}$ and purified by $\mathrm{CsCl}$ discontinuous gradient ultracentrifugation $(45,000 \times g, 6 \mathrm{~h})$ [27]. The obtained purified stocks were dialyzed and stored at $4{ }^{\circ} \mathrm{C}$ for all experiments.

\subsection{Phage Genome Sequencing and Analysis}

To determine the nature of phages (obligatory lytic or temperate) and other properties, the genomes of five phages of the Vojvodinavirus genus (LK3, CN1, CN2, MW2 and FP1) were sequenced and analysed. Their genomic DNA was obtained from the $\mathrm{CsCl}$ purified phage suspensions after a standard phenol/chloroform extraction and ethanol precipitation, followed by RNase treatment and DNA reprecipitation. The whole genome sequencing of phages was performed using Illumina technology, while the de novo assembly of sequenced fragments was carried out using CLC Genomics Workbench 6.5. ORFs (Open Reading Frames) were predicted using GeneMarkS [28]. The analysis of each ORF was performed using the BLAST algorithm, which enabled the comparison and identification of nucleotide and protein sequences with the sequences deposited in database [29]. The presence of tRNA in the phage genomes was analysed using tRNAscan-SE [30]. 


\subsection{Structural Protein Analysis}

Phage LK3 virion structural proteins were concentrated from CsCl-purified samples using methanol precipitation [31]. Extracted proteins were treated with Loading Buffer (Tris-HCl, $\mathrm{pH} 9 ; 0.5 \mathrm{molL}^{-1}$; SDS $4 \%$ w/v; glycerol $10 \%$ v/v; bromphenol blue $10 \%$ w/v; 2-merkaptoethanol $10 \% v / v$ ) prior to heating at $95{ }^{\circ} \mathrm{C}$ for $10 \mathrm{~min}$. The separation of proteins and a standard (PierceTM Unstained Protein MW Marker, Thermo Fisher Scientific, Vilnius, Lithuania) were performed using $10 \%$ w/v polyacrylamide gel and Eco-Medium Electrophoresis System (Biometra, Göttingen, Germany) at $200 \mathrm{~V}$ for $100 \mathrm{~min}$. SDS-PAGE gel was stained using EZBlue Gel Staining Reagent (Sigma-Aldrich, St. Louis, MO, USA), destained in distilled water and documented by BioDocAnalyze Transiluminator (Biometra, Göttingen, Germany).

\subsection{Phage Sensitivity to Environmental Factors}

The effect of different physical and chemical factors on B. bronchiseptica phage (LK3, $\mathrm{CN} 2$, MW2 and FP1) infectivity was examined, including temperature, $\mathrm{pH}$, sodium chloride, and urea. In brief, after $30 \mathrm{~min}$ of $10^{5}$ plaque-forming units (PFUs) $\mathrm{mL}^{-1}$ phage exposure to different temperatures $\left(4,37,45,55,65\right.$ and $\left.75^{\circ} \mathrm{C}\right)$, $\mathrm{pH}$ values $(1.5,3,5,7,9$ and 11$)$, urea concentrations $(0.5,1,3,5,7.5$ and $10 \mathrm{M})$ and sodium chloride concentrations $(1.5,3,5,7.5$ and $10 \%)$, treated suspensions were mixed with soft top agar containing the original host B. bronchiseptica ATCC 10580. The inoculated top agar was poured onto LB agar and after overnight incubation at $37^{\circ} \mathrm{C}$, the plaques were counted. The experiment was carried out in duplicate on two independent occasions. The results were presented as the percentage of infected phages in the suspensions after treatment. The relation between the starting phage PFUs and the obtained values were presented as mean $\pm \mathrm{SD}$.

\subsection{In Vitro Inhibition of Bacterial Growth and Biofilm Formation by Phages}

Three B. bronchiseptica siphoviruses (LK3, CN2 and FP1) were selected based on their host range, RFLP profiles and whole genome-sequencing results Their lytic efficacy were examined against the original hosts (B. bronchiseptica 10580) according to the method of McLaughlin (2007) [32] modified by Knezevic and Petrovic (2008) [33]. In a sterile microtiter of 96-well flat bottom plates, $50 \mu \mathrm{L}$ of double strength LB were inoculated with a final bacterial concentration of $\sim 5 \times 10^{5} \mathrm{CFU} \mathrm{mL} \mathrm{m}^{-1}$ and an equal volume of 10 -fold serial phage dilutions in SM buffer were added (final volume $100 \mu \mathrm{L}$ ). The number of phages in wells were between $1 \times 10^{2}$ and $1 \times 10^{6} \mathrm{PFU} \mathrm{mL}^{-1}$, and these corresponded to the multiplicity of infection (MOI) in the range of 0.001-10. Controls containing only an inoculated medium with sterile SM buffer (bacterial growth control), or SM buffer and uninoculated doublestrength LB (sterility control) were also included. After $24 \mathrm{~h}$ incubation at $37^{\circ} \mathrm{C}$, all wells were amended with $0.1 \%$ 2,3,5-trifenil tetrazolium chloride (TTC) in a final concentration of $200 \mu \mathrm{LmL}^{-1}$. After additional $4 \mathrm{~h}$ incubation, TTC was reduced to red formazan in wells with viable bacteria. Absorbance was measured by a Multiscan GO (Thermo Fisher Scientific, Lithuania) microtiter plate reader at $540 \mathrm{~nm}$. The absorbances were used to estimate the lytic efficacy of the phages using previously described calculations $[33,34]$. The experiments were carried out in duplicate in a minimum of two repetitions, and the results were presented as mean values of bacterial growth inhibition (\%) with standard deviation.

\subsection{Phage Effect on B. bronchiseptica Biofilm Formation}

The determination of phage effectiveness on biofilm formation was analysed by a method developed by Knezevic and Petrovic, 2008 [33]. The effect of LK3, CN2 and FP1 phages was examined against the original host, B. bronchiseptica ATCC 10580. The content of the well was identical to the one mentioned above in the lytic efficiency experiment. Bacteria were grown in a LB medium, and after incubation every well was washed tree times with PBS ( $\mathrm{pH}$ 7.4), after which the plates were dried, and the biofilm was fixed for 15 min with $150 \mu \mathrm{L}$ of methanol. Upon removal of the fixative, the plates were washed with 
tap water, air-dried, stained for $20 \mathrm{~min}$ with $150 \mu \mathrm{L}$ of $0.4 \%$ crystal violet and finally the excessive stain was removed with tap water. The plates were dried at $44{ }^{\circ} \mathrm{C}$ for $20 \mathrm{~min}$. The stain was diluted in glacial acetic acid (33\%) for $20 \mathrm{~min}$, and the absorbances in the wells were measured using a Multiscan GO microtiter plate reader (Thermo Fisher Scientific, Lithuania) at $595 \mathrm{~nm}$. Every phage-bacteria combination was conducted in at least two repetitions and two independent experiments. The results were presented graphically, and calculations were the same for determining phage lytic efficacy.

\subsection{Phage Effect on 24-h Old B. bronchiseptica Biofilm}

The effect of LK3, CN2 and FP1 phages on already-formed biofilm was examined after bacterial growth in an LB medium at $37^{\circ} \mathrm{C}$ for $24 \mathrm{~h}$. After incubation, all wells were washed tree times with PBS ( $\mathrm{pH} 7.4)$, and double-strength LB, and the same volume of phage 10 -fold dilutions were added to the wells. After additional incubation at $37^{\circ} \mathrm{C}$ for $24 \mathrm{~h}$, the plates were treated as described for biofilm formation inhibition.

\subsection{Phage Genome Presence in Bacteria upon Infection}

To infect bacteria with phage, B. bronchiseptica strains (ATCC 10580, Bbchiot and 3416), which are sensitive to phage LK3, were incubated at $37^{\circ} \mathrm{C}$ for $30 \mathrm{~min}$ at MOI $0.1,1,10$ and 100. After incubation, single colonies were picked and cultivated on MacConkey agar and further subcultivated the same way at least twice. To confirm phage infection, genomic DNA were isolated from bacteria using a commercial GeneJET DNA purification kit (Thermo Scientific, Lithuania). Prior to DNA extraction, the cells were washed three times with PBS (NaCl $137.00 \mathrm{mmolL}^{-1}, \mathrm{KCl} 2.70 \mathrm{mmolL}^{-1} \mathrm{Na}_{2} \mathrm{HPO}_{4} 4.30 \mathrm{mmolL}^{-1}, \mathrm{KH}_{2} \mathrm{PO}_{4}$ $1.47 \mathrm{mmolL}^{-1}$.) to remove potential phages that did not infect bacteria. A PCR was applied for phage genome detection in bacteria, using two pairs of specific LK3 phage primers (Bbr-targeting ribonucleotide-diphosphate reductase subunit alpha and Hem-targeting virion structural protein) and a pair of B. bronchiseptica housekeeping gene rec $A$ primers as a control (Table 1). Thermal cycling conditions were as follows: an initial cycle of $94{ }^{\circ} \mathrm{C}$ for $5 \mathrm{~min}$ followed by 35 cycles of $94{ }^{\circ} \mathrm{C}$ for $30 \mathrm{~s}$, annealing at $55^{\circ} \mathrm{C}$ for $30 \mathrm{~s}$, and extension at $72{ }^{\circ} \mathrm{C}$ for $30 \mathrm{~s}$, with a final $7 \mathrm{~min}$ extension at $72{ }^{\circ} \mathrm{C}$. PCR products were analysed on $1 \%$ agarose gel with ethidium bromide. A positive control was phage DNA and a negative one was distilled water. The gels were documented using BioDocAnalyze Transiluminator (Biometra, Germany). In addition to conventional PCR, restriction enzyme digestion was used to confirm phage infection. Briefly, DNA of lysogenic and non-lysogenic bacteria was treated with Sall fast-digest enzyme (Thermo Scientific, Lithuania) for $15 \mathrm{~min}$ at $37^{\circ} \mathrm{C}$, followed by fragments separation on $1 \%$ of agarose gel. The SalI enzyme cuts bacterial DNA producing great number of small fragments that appear on the gel as a smear. The phage genome does not contain a SalI-specific sequence, so the enzyme does not digest the phage DNA that appears on the gel as the highest clear single band. The DNA of non-lysogenic bacteria treated with Sall and phage LK3 genomic DNA were used as controls.

Table 1. Primers used in the study.

\begin{tabular}{cccc}
\hline $\begin{array}{c}\text { Label of } \\
\text { Primer }\end{array}$ & \multicolumn{1}{c}{ Sequence $\left(\mathbf{5}^{\prime} \rightarrow \mathbf{3}^{\prime}\right)$} & Expected Product (bp) & Reference \\
\hline $\begin{array}{c}\text { Bbr-F } \\
\text { Bbr-R }\end{array}$ & $\begin{array}{c}\text { TGA CTT CAT GGT TGC CGT TC } \\
\text { TCG GGA GCG TGA TTT CAG TA }\end{array}$ & 241 & {$[23]$} \\
\hline Hem-F & ACG CCC GAA CCG TTA TTT GG & 170 & This study \\
Hem-R & CAT TTC CCC GCA ACT CGA CA & & [23] \\
\hline RecA-F & ATG GCG ACA ACG AGG TCG AA & 263 \\
RecA-R & CAG CAG GTC GGT CAG GTT GA & & \\
\hline
\end{tabular}




\subsection{Phenotypic Changes of lysogenic B. bronchiseptica}

2.10.1. Biofilm Production of Lysogenic Bacteria

To determine the biofilm formation potential of lysogenic bacteria, the previously described method by Stepanovic et al., 2000 was used [35]. Briefly, both lysogenic (ATCC10580+, Bbchiot+ and Bbr3416+) and non-lysogenic (ATCC10580, Bbchiot and Bbr3416) bacterial strains were grown in LB medium over $48 \mathrm{~h}$. After incubation, every strain was washed tree times with sterile distilled water and the number of bacteria was adjusted to $\sim 2 \times 10^{3}, 2 \times 10^{5}$ and $2 \times 10^{7} \mathrm{CFU} \mathrm{mL}{ }^{-1}$. In two separated microtiter plates, $200 \mu \mathrm{L}$ of bacterial suspension was added, and both plates were placed at $37^{\circ} \mathrm{C}$; one plate was incubated for $24 \mathrm{~h}$ while the second one was incubated for $48 \mathrm{~h}$. The LB medium without bacteria was used as a negative control and a Pseudomonas aeruginosa PAO1 reference strain was used as a positive control in the experiment. After incubation, all wells, including controls, were washed three times with PBS (pH 7.4) to remove planktonic cells that were not part of the biofilm. Formed biofilm was fixed with $150 \mu \mathrm{L}$ of methanol for $15 \mathrm{~min}$, after which the methanol was removed and the plates were dried in an incubator at $44{ }^{\circ} \mathrm{C}$ for $20 \mathrm{~min}$. Dried plates were stained with $0.4 \%$ crystal violet solution for $15 \mathrm{~min}$, after which the stain was removed by washing the plates with water. The plates were then placed back into the incubator at $44{ }^{\circ} \mathrm{C}$ for $15-20 \mathrm{~min}$ to dry. After incubation, $150 \mu \mathrm{L}$ of $33 \%$ acetic acid was added in each well to dissolve the stain from biofilm. Absorbance was measured on Multiscan GO (Thermo Scientific, Lithuania) plate reader at $595 \mathrm{~nm}$. The experiment was carried out in triplicate and on three independent occasions. The results were presented graphically, as mean value of absorbance with standard deviation.

\subsubsection{Hemolytic Activity of Lysogenic Bacteria}

To determine if there were a significant difference in hemolytic activity between non-lysogenic and lysogenic bacterial strains, the method described by Janda and Abbott, 1993 [36] was used. In this experiment, a 1\% erythrocyte solution was extracted from blood (sheep, rat and cow) in $0.9 \%$ sodium chloride, after which the erythrocyte solution was mixed with bacterial suspensions ( $1.5 \mathrm{McF}$ arland). The mixture was incubated at $37^{\circ} \mathrm{C}$ for $48 \mathrm{~h}$ after which the released hemoglobin was quantified using the microtiter plate reader Multiscan GO (Thermo Fisher, Lithuania) at $540 \mathrm{~nm}$. The 1\% SDS solution was used as a positive control, while $0.9 \%$ sodium chloride was used as a negative control. The obtained values were analysed in STATISTICA 12.0, using the Student's t-test to determine if there were a statistically significant difference in the hemolysis of erythrocytes between non-lysogenic and lysogenic strains.

\subsubsection{Susceptibility of Lysogenic Bacteria to Antibiotics}

The susceptibility of lysogenic bacteria antibiotics was determined by standard diskdiffusion methods (Kirby-Bauer) and according to CLSI (2007). A total of 20 antibiotics from different classes were used in the experiment: beta-lactams (ampicillin $(10 \mu \mathrm{g})$, amoxicillin $(25 \mu \mathrm{g})$, amoxicillin/clavulanic acid $(20 / 10 \mu \mathrm{g})$, cefalexin $(30 \mu \mathrm{g})$, cefoxitin $(30 \mu \mathrm{g})$, ceftazidime (30 $\mu \mathrm{g})$, cefotaxime $(30 \mu \mathrm{g})$ and imipenem $(10 \mu \mathrm{g})$ ); aminoglycosides (amikacin $(30 \mu \mathrm{g})$, gentamicin $(10 \mu \mathrm{g})$, streptomycin $(10 \mu \mathrm{g})$, kanamycin $(30 \mu \mathrm{g})$, tobramycin $(10 \mu \mathrm{g})$, netilmicin $(30 \mu \mathrm{g})$ and neomycin $(30 \mu \mathrm{g})$ ], tetracycline [tetracycline $(30 \mu \mathrm{g})$ and doxycycline $(30 \mu \mathrm{g})$ ], phenicol [chloramphenicol $(30 \mu \mathrm{g})$ ); fluoroquinolones (ciprofloxacin $(5 \mu \mathrm{g})$ ); macrolides (aztreonam $(30 \mu \mathrm{g})$ ); and sulphonamides (sulfamethoxazole/trimethoprim $(23.75 / 1.25 \mu \mathrm{g}))$. Testing was done in two independent experiments and the values (i.e., diameters of inhibition zone by antibiotic) were analysed in STATISTICA 12.0 software using the Student's $t$-test to determine significant differences in sensitivities to antibiotics between lysogenic and non-lysogenic B. bronchiseptica strains. Escherichia coli ATCC 25922 was used as a control. Results were expressed the average values of two experiments + SD.

\subsubsection{Swimming and Twitching Motility of Lysogenic Bacteria}

Flagellar motility, also known as swimming motility, was examined in lysogenic bacteria using the method described by Kerns (2010) [37]. Briefly, bacteria were inoculated 
in the center of a semisolid LB Agar $(0.3 \%)$ using a sterile needle. Both plates with lysogenic and non-lysogenic bacteria were incubated at $37^{\circ} \mathrm{C}$ for $48 \mathrm{~h}$. Following incubation, the diameter of the colony was measured, and the results presented as average $+\mathrm{SE}$. The flagella-independent form of motility, also known as twitching motility, was examined in lysogenic bacteria using standard LB Agar. Lysogenic and non-lysogenic bacteria were inoculated by a sterile needle in the center of the plate. Following incubation $\left(37^{\circ} \mathrm{C}\right.$ for $48 \mathrm{~h}$ ), the diameter of colony was measured in a Petri dish and medium interface and the results were presented as average $+\mathrm{SE}$. Both swimming and twitching motility experiments were performed in duplicate in two independent occasions and the Pseudomonas aeruginosa reference strain PAO1 was used as a control.

\subsubsection{Fimbria Production}

To better understand the phage role in B. bronchiseptica pathogenicity, the production of fimbria in lysogenic bacteria was also examined. For this purpose, the adapted method described by Jain and Chen (2007) was used [38]. Briefly, bacteria were cultured in LB Agar containing $0.5 \%$ sodium chloride and subsequently incubated for 5 days at 26 and $37^{\circ} \mathrm{C}$. After incubation, bacteria were suspended in $0.9 \%$ sodium chloride to $\sim 1 \times 10^{9} \mathrm{CFU} \mathrm{mL} \mathrm{mL}^{-1}$. Bacterial suspension was then centrifuged $(16,000 \times g, 10 \mathrm{~min})$ to obtain the pellet. A solution of $0.002 \%$ Congo red was used to resuspend the bacterial pellet and the absorbance was measured at $500 \mathrm{~nm}$. The results were presented as a percentage of reduced Congo red that was bound by fimbriae in comparison to the sterile solution without bacteria. Escherichia coli ATCC 25922 was used as a control.

\section{Results}

\subsection{Bordetella Phage LK3 Genome Properties}

Complete genomic sequences of phages were deposited with GenBank under accession numbers KX961385 (LK3), KY000218 (MW2), KY000219 (CN2), KY000220 (FP1) and KY000221 (CN1). The genome of LK3 phage consisted of double-stranded DNA with a length of $59,831 \mathrm{bp}$ and $\mathrm{G}+\mathrm{C}$ composition of $64.01 \%$, with no tRNA detected. Among the total of 78 ORFs (GeneMark), 32 (40.5\%) were identified as hypothetical proteins (Figure 1).

The LK3 genome also contains eight ORFs that shows no similarity with sequences from the GenBank database. The predicted ORFs were roughly classified into three functional regions: (i) nucleotide metabolism and DNA replication, (ii) host interaction, and (iii) virion structure and packaging with lysis cassette (Figure 2). Putative genes encoding repressor protein (ORF52) and integrase (ORF53) were detected in the genome, similar to the integrase of Pseudomonas phage MP1412 at 99\% and Pseudomonas phage PAE1 at $100 \%$, respectively, which indicated the temperate nature of the phage. Nevertheless, LK3 also possessed genes coding for DNA polymerase, primase and helicase, which are involved in replication. A few genes involved in the host interaction were also detected, such as diguanylate cyclase with GGDEF domain and an anti-restriction enzyme. The lytic cassette of LK3 phage displayed similarity with other phages that infect Gram-negative bacteria and consists of four overlapping genes: spanins, endolysin and holine. Analysis of endolysin sequence revealed the lytic transglycosylase muralytic activity, globular structure, and presence of signal peptide sequence. 


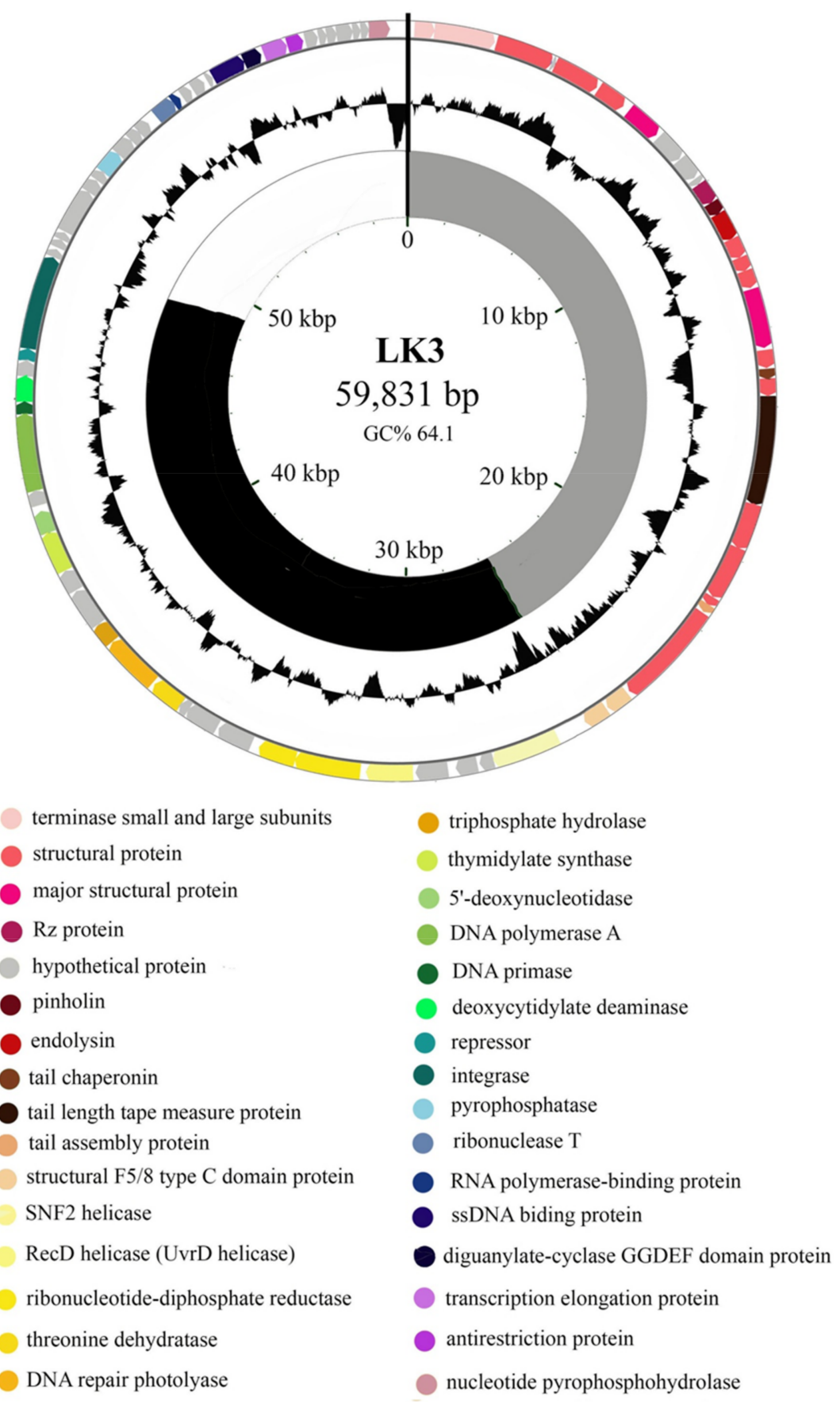

Figure 1. Genomic map of circularly permuted vB_BbrS_LK3 Bordetella phage dsDNA: the outer ring illustrates the encoded genes/ORFs with putative functions indicated in the legend below the circle; the central ring represents GC\% content in the genome; the inner ring represents modules: (i) nucleotide metabolism and DNA replication (black); (ii) host interaction module (white), and (iii) particle structure and packaging module with lysis cassette (grey).

The whole genome phylogeny showed high sequence similarity among the five $B$. bronchiseptica siphoviruses. (>88\%) and relatively high homology to Pseudomonas Yua-like siphoviruses (>40\%); highest similarity was recorded with LKO4 (52.6\%) and Yua (44.7\%) phages [24]. Based on these results, phages were selected for further characterisation which included testing of sensitivity to different environmental factors (LK3, CN2, FP1 and MW2) and their lytic efficacy against their original host (LK3, CN2, FP1). 


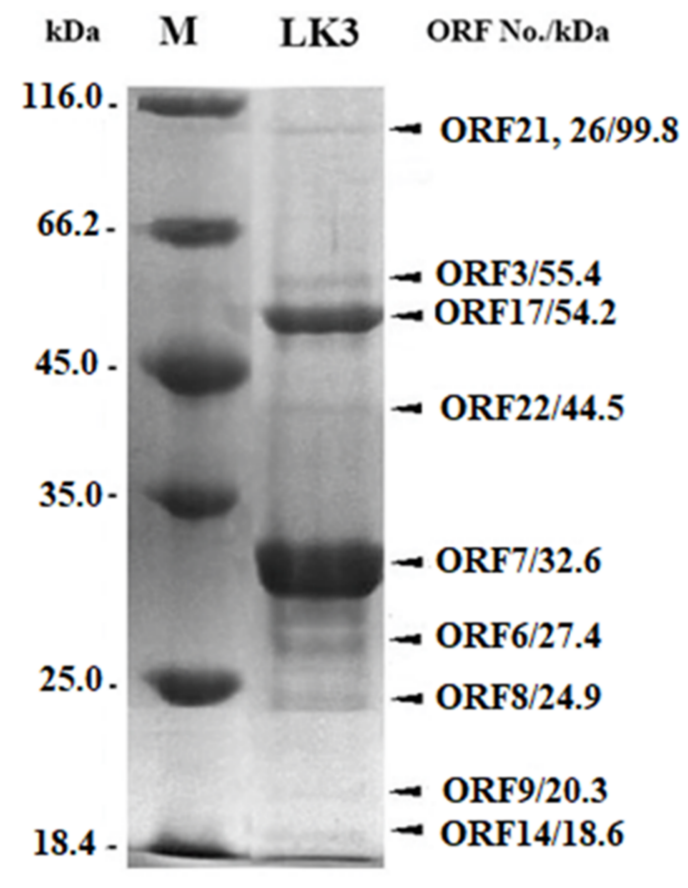

Figure 2. 1D SDS-PAGE of phage LK3 virion proteins; $M$ - protein marker. Each band is designated with appropriate ORF and the difference between the predicted and obtained proteins' MW was less than $5 \%$.

\subsection{Proteomic Characterization of LK3 Phage}

Structural proteins of LK3 phage were analyzed by 1D sodium dodecyl sulfatepolyacrylamide gel electrophoresis (SDS-PAGE) and at least 9 protein bands of $\sim 18-100 \mathrm{kDa}$ were detected, including major capsid proteins with a molecular weight of $\sim 32.5$ and $54.2 \mathrm{kDa}$ (Figure 2). All bands corresponded to predicted structural proteins in silico, with an acceptable error of molecular weight of less than $5 \%$ [39].

\subsection{Phage Resistance to Environmental Factors}

All phages were stable in a $\mathrm{pH}$ range of 3-11 for $30 \mathrm{~min}$, and all lost infectivity at $\mathrm{pH}$ 1.5 (Figure 3A). Only phage FP1 was affected by $5 \% \mathrm{NaCl}$ as this concentration reduced the number of virions by more than $50 \%$, while the other phages were resistant even to $10 \%$ $\mathrm{NaCl}$ for $30 \mathrm{~min}$ (Figure 3B). The number of FP1 and MW2 virions was reduced by half at $65^{\circ} \mathrm{C}$ for $30 \mathrm{~min}$, while all phages were inactivated at $75^{\circ} \mathrm{C}$ (Figure 3C). Similarly, $7.5 \mathrm{M}$ of urea reduced the number of FP1 and MW2 phages by half, while for phages CN2 and LK3 the same effect was obtained with $10 \mathrm{M}$ of urea for $30 \mathrm{~min}$ (Figure 3D).

\subsection{Phage Inhibition of Bacterial Growth and Biofilm Formation}

The results of bacterial growth, biofilm inhibition and biofilm removal by LK3, CN2 and FP1 phages are shown in Figure 4.

All bacteriophages exhibited relatively high efficacy of lysis on original host B. bronchiseptica ATCC 10580. Even at the lowest MOI, inhibition of bacterial growth was considerable (85\%), with maximal inhibition reached at MOI 1 (>99\%) (Figure $4 \mathrm{~A})$. The results of biofilm inhibition (Figure 4B) and biofilm removal (Figure 4C) indicated that all phages had a similar effect on B. bronchiseptica ATCC 10580 biofilm. At the lowest MOI, inhibition of biofilm formation was $70 \%$, while maximal inhibition was reached at MOI 1 and MOI 0.1 $(>90 \%)$, in LK3/FP1 phages and the CN1 phage, respectively. However, phages showed lower efficacy on $24 \mathrm{~h}$-old biofilm compared to biofilm in the formation stage. The lowest efficacy in biofilm reduction was at MOI 1 for LK3 (approx. 40\%). Regardless of the results, the efficacy of phages on existing biofilm was still considerably high, with the highest efficacy reached by the same phage at MOI $0.01(<80 \%)$. 

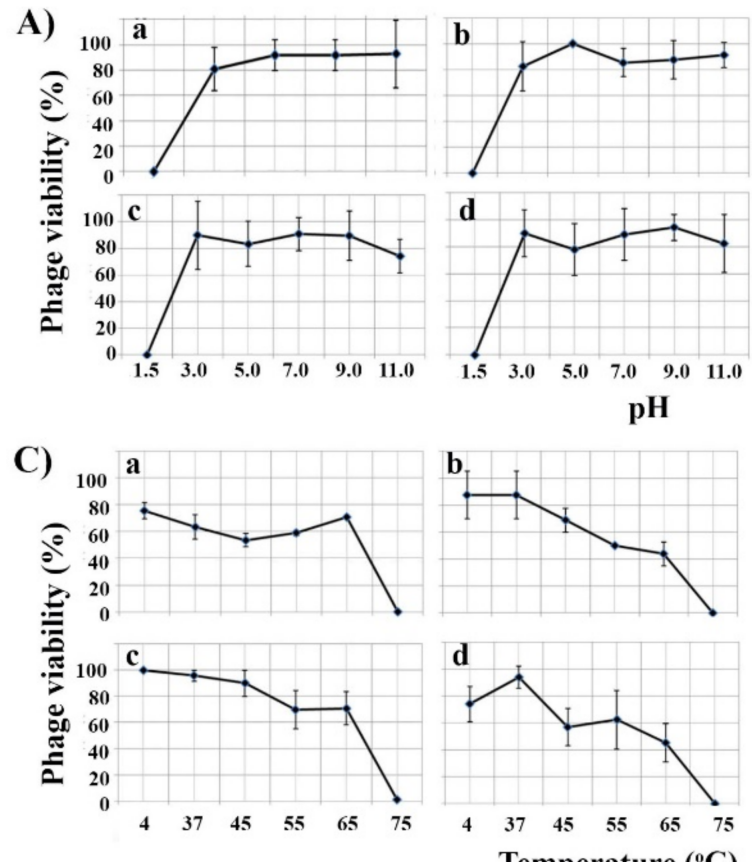

Temperature $\left({ }^{\circ} \mathrm{C}\right)$
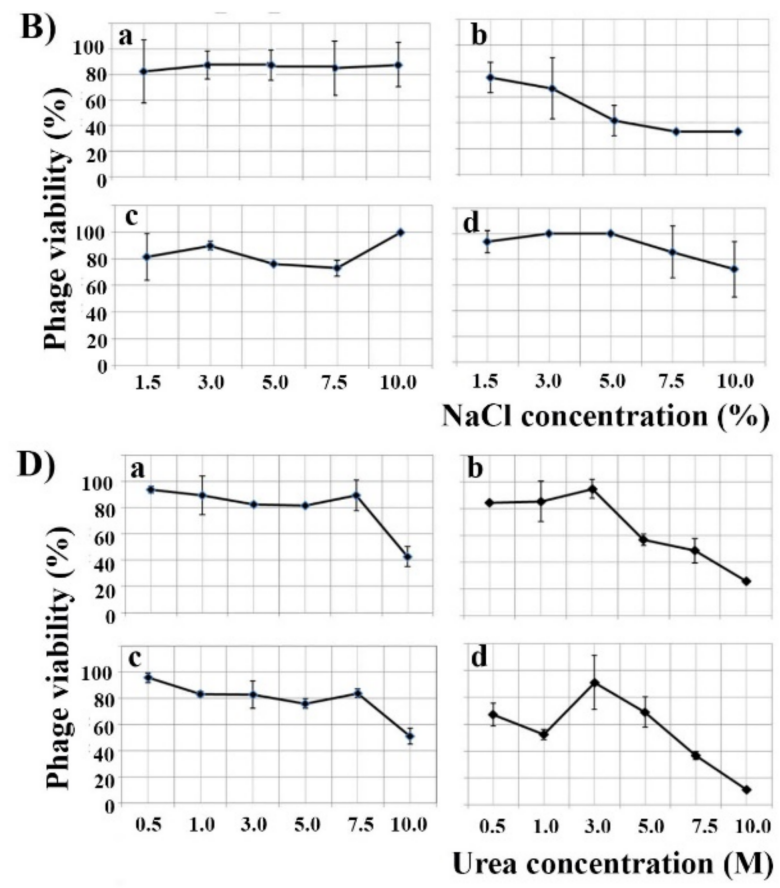

Figure 3. Effect of different $\mathrm{pH}(\mathbf{A}), \mathrm{NaCl}$ concentrations (B), temperatures (C) and urea concentrations (D) on the infectivity of B. bronchiseptica phages CN2 (a), FP1 (b), LK3 (c) and MW2 (d).
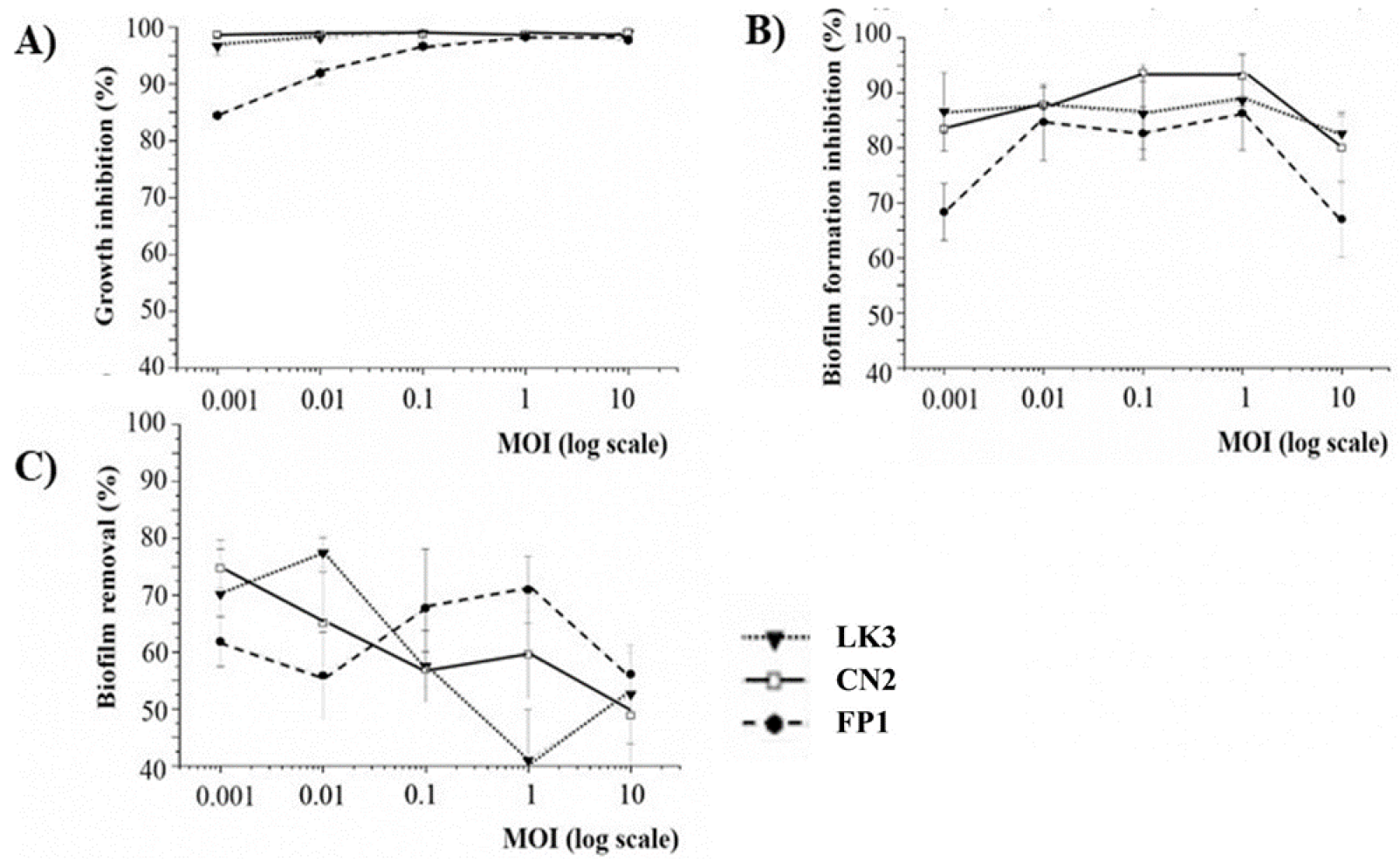

Figure 4. Bacterial growth inhibition (A), inhibition of biofilm formation (B) and removal of B. bronchiseptica ATCC 10580 biofilm $(\mathrm{C})$ by siphoviruses: LK3 $(\boldsymbol{\nabla}), \mathrm{CN} 2(\square)$ and FP1 $(\bullet)$.

\subsection{Confirmation of LK3 Infection and Stability of Lysogens}

To confirm B. bronchiseptica infection with LK3 phage (ATCC 10580+, Bbchiot+ and Bbr3416+), PCR was used for two pairs of phage-specific primers (Bbr and Hem). The 
expected products, $241 \mathrm{bp}$ for $\mathrm{Bbr}$ and $170 \mathrm{bp}$ for Hem primer pairs, were detected in the genomic DNA of LK3 lysogenic bacterial strains (Figure 5A-C). Restriction digestion with enzyme Sall additionally confirmed infection of B. bronchispetica strains with LK3 phage (Figure 5D), as the enzyme cut bacterial DNA on a huge number of fragments, but the phage DNA stayed intact and appeared on the gel as the highest uncut fragment. The results of the experiments for stable phage genome persistence in bacteria indicated that B. bronchiseptica LK3 phages formed unstable lysogens with the original host ATCC 10580 (Figure 5E). Namely, after the third subcultivation of the lysogenic strain, the expected Hem PCR product was not detected, indicating absence of phage DNA in the strain. The other two lysogenic strains, Bbchiot+ and Bbr3416+, showed greater stability, as the PCR product was detected even after the sixth subcultivation, both in genomic and plasmid DNA.

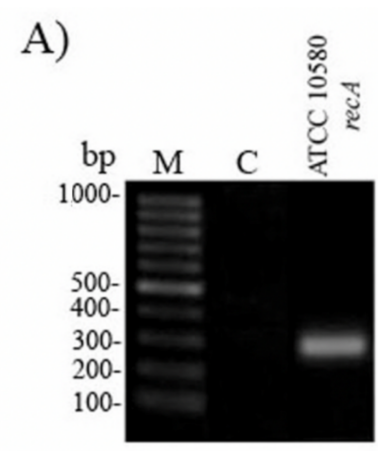

C)

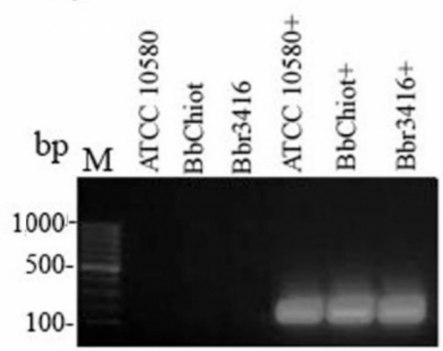

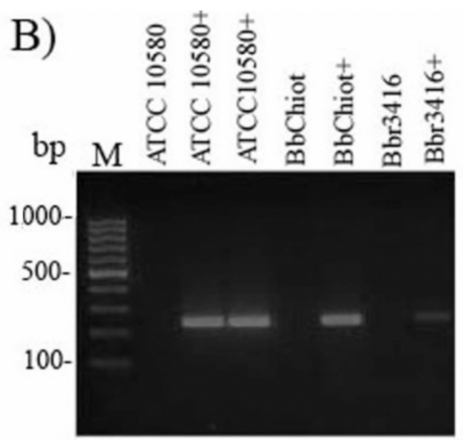

D)

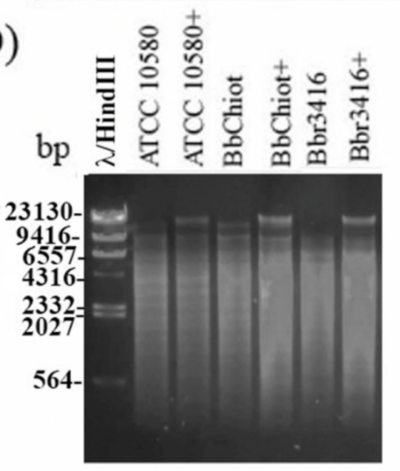

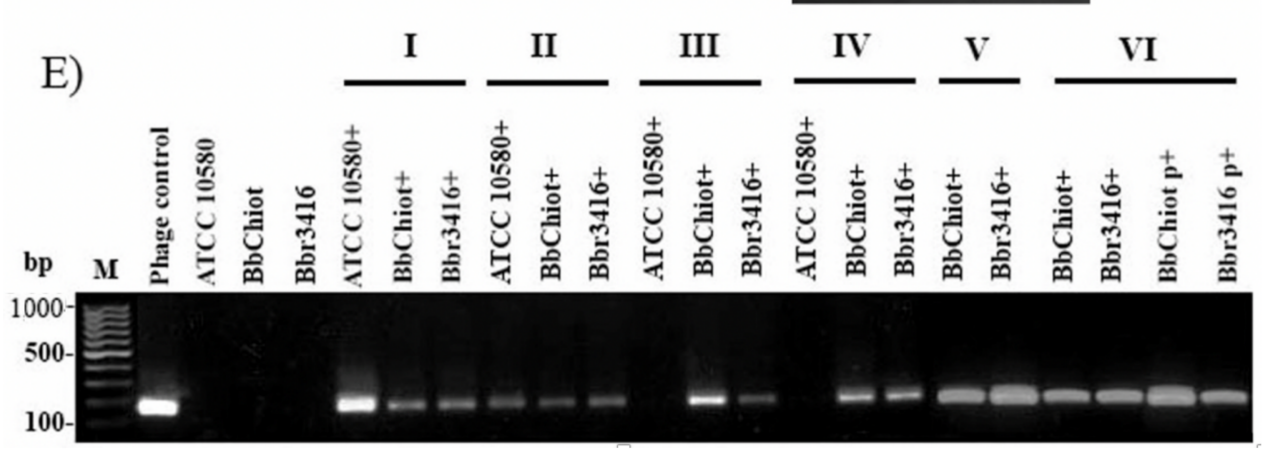

Figure 5. Confirmation of phage DNA presence in genomic DNA of bacterial strains ATCC 10580, BbChiot and Bbr3416 upon infection: (A) Quality control of bacterial DNA with Bbr-recA primers; (B) Infection confirmation with specific primers Bbr-R and Bbr-F (product size $241 \mathrm{bp)}$ ); (C) Infection confirmation with specific primers Hem-R and Hem-F (product size $170 \mathrm{bp}$ ); (D) Infection confirmation of bacterial strains ATCC 10580, BbChiot and Bbr3416 with restriction digestion with enzyme SalI; phage DNA in lysogenic strain stayed intact.; (E) Presence of viral DNA in bacterial genomic DNA of strains ATCC 10580, BbChiot and Bbr3416 during six successive transfers onto a new medium confirmed by primer pairs Hem (I-VI); M-DNA ladder $100 \mathrm{bp}$; (C) a negative control; (+) lysogenic strain with phage. 


\subsection{Lysogenic Conversion of B. bronchiseptica by LK3 Siphovirus}

The potential of both non-lysogenic and lysogenic cells to form biofilm was examined using various starting bacterial numbers $\left(\sim 2 \times 10^{3}, 2 \times 10^{5}\right.$ and $\left.2 \times 10^{7} \mathrm{CFU} \mathrm{mL}{ }^{-1}\right)$ (Figure $6 \mathrm{~A}-\mathrm{C}$ ). Lysogenic strains showed increased adherent and aggregative growth in broth culture (Figure 6C tube), with an exception for the LK3 lysogenic strain ATCC10580+ and Bbchiot+ at inoculum $\sim 2 \times 10^{3} \mathrm{CFU} \mathrm{mL}{ }^{-1}$ after $24 \mathrm{~h}$.

After $24 \mathrm{~h}$
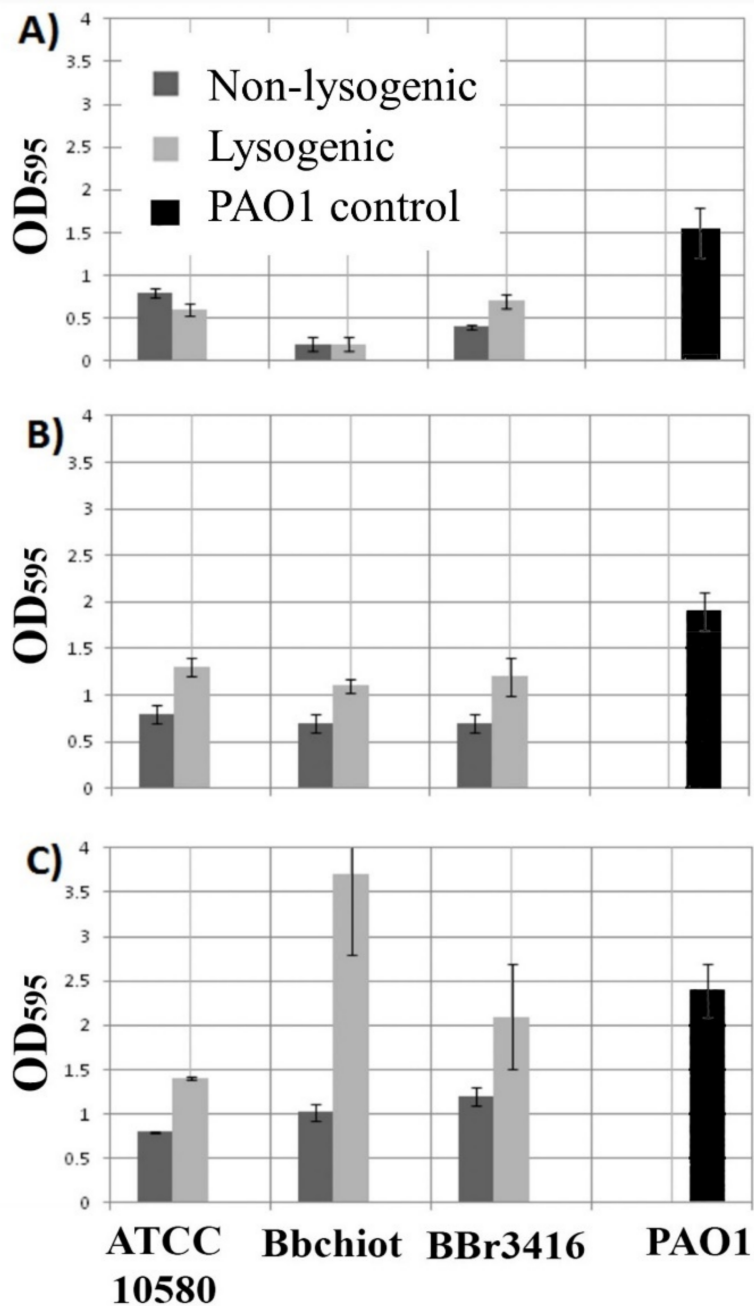

After 48 h
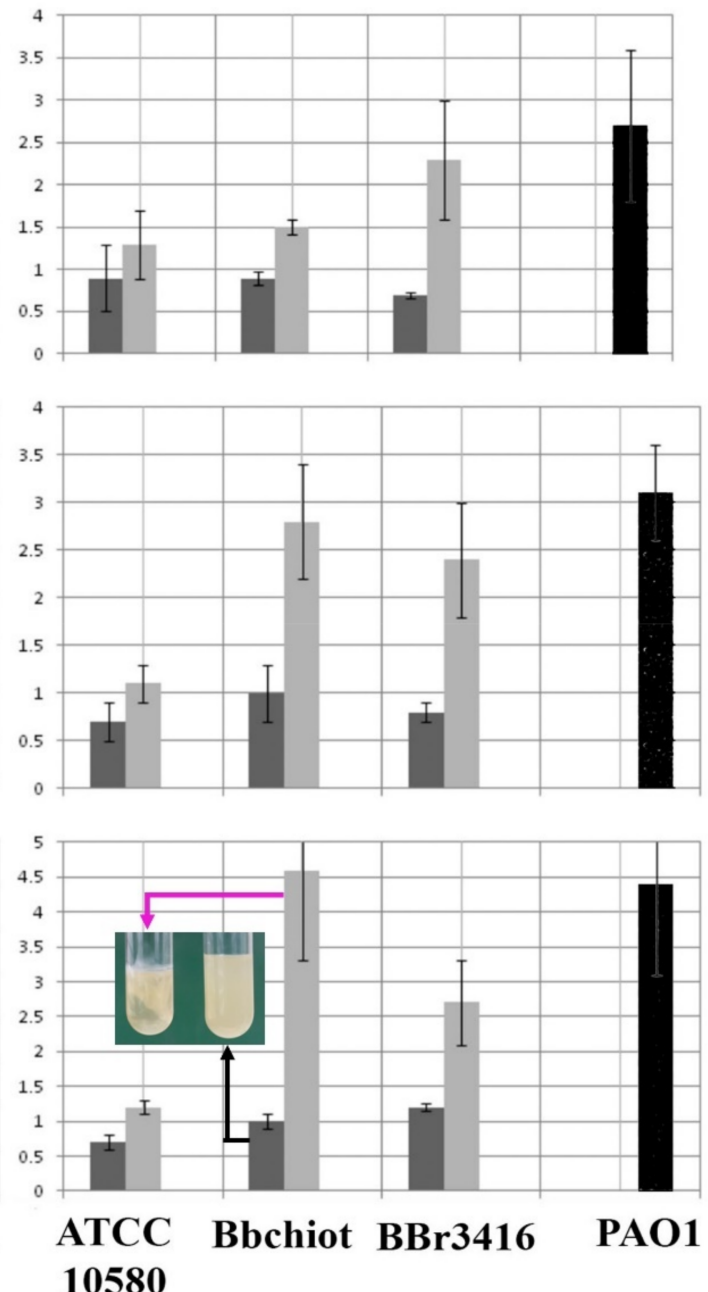

Figure 6. Biofilm production by non-lysogenic and lysogenic B. bronchiseptica strains after 24 and $48 \mathrm{~h}$ incubation. Starting concentration of bacteria $\sim 2 \times 10^{3} \mathrm{CFU} \mathrm{mL}^{-1}(\mathbf{A}), \sim 2 \times 10^{5}(\mathbf{B})$ and $2 \times 10^{7}$ (C).

With the exception of these two cases, at all starting bacterial numbers lysogenic strains showed statistically significant higher biofilm production after $24 \mathrm{~h}$ in comparison with non-lysogenic strains $(p<0.01)$. A statistically significant difference was also determined between lysogenic and non-lysogenic strains of B. bronchiseptica after $48 \mathrm{~h}$ incubation $(p<0.01)$ (Figure $5 \mathrm{~B})$. It is also interesting to note that some strains (Bbchiot+ and Bbr3416+) formed 2-4 times more biofilm compared to wild types. The results of other phenotypic testing on lysogenic bacteria (ATCC 10580+) are summarized in Table 2. Upon infection of the ATCC 10580 strain with phage LK3 (ATCC 10580+), an increase of sheep blood hemolysis was noticed, while this activity against rat and cattle blood did not change significantly. The phage increased flagellar motility of Bbchiot strain, while phage infection had no effect on twitching motility and fimbria production. A change in antibiotic susceptibility was also observed, most prominently against amoxicillin/clavulanic acid: as an intermediate-sensitive strain, ATCC 10580 became resistant, and the sensitive Bbchiot 
strain became intermediately sensitive. A similar change from the intermediate-sensitive strain Bbchiot to resistant was confirmed for ceftazidime. Although LK3 changed the inhibition zone diameter around discs of doxycycline and sulfamethoxazole/trimethoprim, the bacteria remained sensitive. Sensitivity to other antibiotics did not change significantly.

Table 2. Phenotypic changes of bacterial characteristics upon infection with Bordetella phage LK3.

\begin{tabular}{|c|c|c|c|c|c|}
\hline & & \multicolumn{4}{|c|}{ Strains } \\
\hline \multicolumn{2}{|c|}{ Characteristics } & ATCC10580 & ATCC10580+ & Bbchiot & Bbchiot+ \\
\hline \multirow{3}{*}{$\begin{array}{c}\text { Hemolysis } \\
(\%)\end{array}$} & Sheep blood & $14.3 \pm 3.7$ & $26 \pm 0.28 *$ & N.T. & N.T. \\
\hline & Rat blood & $47 \pm 6.8$ & $38.1 \pm 6.1$ & N.T. & N.T. \\
\hline & Cattle blood & $66.95 \pm 7$ & $59.1 \pm 12.02$ & N.T. & N.T. \\
\hline \multirow{2}{*}{$\begin{array}{l}\text { Motility } \\
(\mathrm{mm})\end{array}$} & Swimming & $14.6 \pm 0.7$ & $14.4 \pm 1.6$ & $66.9 \pm 2.5$ & $78.2 \pm 1.8$ \\
\hline & Twitching & $4.0 \pm 0.0$ & $4.3 \pm 0.2$ & $5.0 \pm 0.3$ & $4.1 \pm 0.2$ \\
\hline $\begin{array}{c}\text { Fimbria } \\
\text { production }\end{array}$ & Congo-red reduction (\%) & $10.0 \pm 2.1$ & $11,8 \pm 2$ & $9.1 \pm 1.3$ & $8.5 \pm 2.3$ \\
\hline \multirow{4}{*}{$\begin{array}{l}\text { Susceptibility to } \\
\text { antibiotics }{ }^{1}(\mathrm{~mm})\end{array}$} & Amoxicillin/clavulanic acid & $15.8 \pm 2.1$ & $12.1 \pm 0.9^{*}$ & $18.8 \pm 1.0$ & $15.3 \pm 0.9 *$ \\
\hline & Ceftazidime & $17.3 \pm 3.0$ & $16.0 \pm 2.0$ & $20.0 \pm 1.0$ & $13.5 \pm 0.5$ * \\
\hline & Doxycycline & $43.0 \pm 1.2$ & $38.3 \pm 1.0$ & $33.5 \pm 1.7$ & $35.9 \pm 3.6$ \\
\hline & Sulfamethoxazole/Trimethoprim & $25.5 \pm 4.1$ & $19.6 \pm 1.1$ & 0 & 0 \\
\hline
\end{tabular}

${ }^{1}$ Antimicrobials that do not cause change in inhibition diameter are not shown in the table; N.T. stands for not tested; Asterisks * indicate significantly different values based on Student's $t$-test $(p \leq 0.05)$.

\section{Discussion}

B. bronchiseptica siphoviruses had previously been isolated and morphologically characterized, and their host range and RFLP pattern had been determined [23]. All phages displayed mutually high similarity with certain variation, especially regarding RFLP pattern and efficacy of plating. In this study their potential applicability as anti-Bordetella agents and their usability in phage therapy were examined.

The in vitro lytic efficacy of B. bronchiseptica-specific siphoviruses showed up to $99 \%$ total bacterial growth inhibition. The method applied can be considered as an estimation of both the planktonic and biofilm phage effect [34,40,41]. The biofilm formation inhibition indicated that B. bronchiseptica phages are highly efficient at biofilm prevention (up to $93 \%$ for CN1 phage), which was in accordance with the phage inhibition of total bacterial growth; that is, the highest inhibition of both total bacterial growth and biofilm formation by siphoviruses were at MOI 1 . Since absolute inhibition of neither total bacterial growth nor biofilm formation inhibition was achieved at MOI10, it is most likely that the phages were temperate.

The 24 h-old B. bronchiseptica biofilm removal by phages was lower in comparison to biofilm inhibition. The lower percentage of biofilm reduction by siphoviruses can be explained by fact that biofilm is a complex microbial community in which gene expression and receptors for phages are quantitatively and qualitatively different from those in planktonic cells [42]. The importance of pili in the initial phase of B. bronchiseptica biofilm formation was highlighted by Irie et al. [43], and since the LK3 phage displayed DNA sequence similarity with Pseudomonas phage Yua, which has pili as receptors [44], it is very likely that LK3 phage also used these surface structures when adhering to the host cell. Thus, in the complex matrix of biofilm, pili receptors are not available to phages as they are in planktonic cells. Furthermore, bacteria in biofilm are less metabolically active, so phage production is generally reduced as temperate phages integrate with the bacterial genome rather than enter the lytic cycle [45]. Regardless, the lower efficacy of phages in biofilm reduction compared to biofilm formation inhibition, Bordetella phage LK3 generally had a satisfactory effect on biofilm prevention and removal. The relatively high reduction of $24 \mathrm{~h}$-old biofilm can be explained by the fact that extracellular DNA (eDNA), as important 
component of biofilm matrix [46], occurred after $48 \mathrm{~h}$ of B. bronchiseptica incubation [47], so the biofilm had not completely matured.

Taking into consideration that different factors can affect the efficacy of phage therapy, primarily the multiplicity of infection (MOI) [48], in this study the lytic efficacy of LK3, $\mathrm{CN} 1$ and FP1 phages were examined at different MOI $(0.001-10)$ to determine at which MOI value the best antibacterial effect was achieved. It is interesting that highest efficacy was recorded at lower MOI values (0.001-0.1), indicating the potential integration of phage with the bacterial genome [49]. Many authors such as Knezevic et al. [34], suggested that MOI 10 is the most appropriate for a successful antibacterial phages effect because at this MOI each bacterium is infected by at least one phage following the Poisson distribution. However, when temperate phages are examined, the effect of different MOIs on phage lytic activity is different $[15,50]$. One example is the lambda phage, for which phage integrase activity directly depends on the concentration of cell proteases and MOI value: a low concentration of protease or high MOI values enhance integrase activity, which promotes phage entry into the lysogenic cycle. On the other hand, at a low MOI value, integrase activity was reduced to a minimum and the phage did not integrate with the bacterial genome but entered the lytic cycle [49]. Taking into account that the phage did not show enhanced lytic properties at MOI 10, it seems that they were temperate, i.e., able to enter the lysogenic cycle like a lambda phage. Good biofilm removal efficacy was recently observed for a Yuavirus-related Pseudomonas phage Zc01, which was superior in comparison to two Podoviridae and showed efficacy at a very low MOI, approx. 0.01 [51].

To consider phage properties further, the Bordetella phage LK3 genome was sequenced to reveal genes responsible for lysogenization. The LK3 phage displayed high DNA-sequence similarity with a few Yua-related P. aeruginosas phages (MP1412, Yua and LK04) [44,52], and possessed genes for integrase and repressor proteins. These findings indicated that LK3 was capable of integrating into the host's genome, further confirming its temperate nature and, along with the previously confirmed pac site [23], indicating possible phage involvement in transduction [53]. The genome of LK3 also has genes coding for DNA polymerase, primase and helicase and others involved in replication. These genes are part of the replisome, a multiprotein complex that dictates the coordinated synthesis of both leading and lagging DNA [54] and increases replication efficacy [55]. The predicted structural genes corresponded to the protein profile obtained by SDS-PAGE.

For genes involved in host interactions, the most interesting one detected in the LK3 phage genome, apart from integrase and repressor protein, was diguanylate-cyclase with a GGDEF domain, which is involved in global secondary messenger synthesis (cGMP) by controlling motility and biofilm formation in bacteria. This enzyme was previously detected in Pseudomonas-specific phages from the genus Yuavirus and probably contributes to bacteria properties, including those of $B$. bronchiseptica. The LK3 phage does not possess a reverse transcriptase, which had previously been detected in the genome of the temperate B. bronchiseptica phage from the family Podovirirdae and generates nucleotide diversity in the $m t d$ region, responsible for the specificity of receptor molecules [56]. It is worth highlighting the presence of the gene for anti-restriction protein (responsible for the interaction with restriction enzymes and the tail-structural proteins ORF27 and ORF28) that contains the F5 / 8 (discodin) domain of eukaryotic coagulation factor, which specifically binds to phospholipids [57]. Proteins with this domain are not present in other Yua-related phages and probably play a role in the interaction with bacterial cell membranes. Lysis cassettes of LK3 phage consist of genes encoding pinholin, endolysin and spanin (Rz protein), which is generally characteristic of phages that infect Gram-negative bacteria. An analysis of the LK3 endolysin sequence confirmed the presence of a signal peptide sequence, supposed to have a role in membrane integration, and that the existing pinholin contributed to the lytic process by accelerating it and causing membrane depolarization $[58,59]$. The lysin can have practical applications in bacterial growth control with further examination or modification.

Infection experiments confirmed that the LK3 phage genome can persist in the sensitive strains (ATCC 10580, Bbchiot and Bbr3416) because the presence of phage DNA in 
the bacterial genomic DNA was confirmed. The stability of B. bronchiseptica LK3 lysogens was tested through continuous subcultivation of lysogenic strains and infection persistence, i.e., phage DNA presence. Taking into account that the Bbchiot and Bbr3416 strains contained phage DNA after the sixth subcultivation, they formed stable lysogens. Unlike them, the reference strain B. bronchiseptica ATCC 10580 lysogen did not show an equal persistence of phage in the bacterial cell: phage DNA was not detected in bacteria after the third subcultivation of the lysogenic strain, indicating that the LK3 phage formed unstable lysognes of the reference strain. The Bordetella phage LK3 displayed a high degree of morphological and genetic similarity with the Yua phage, which cannot form lysogeny. Specifically, Ceyssens et al. [44] attempted unsuccessfully to confirm the presence of the Yua phage in PAO1 colonies from blurry lysogenic strain plaques using PCR and RFLP. The absence of lysogens was also observed for the related alpha-proteobacterium phage, $\varphi \mathrm{JL} 001[60,61]$. The authors indicated that the Yua integrase requires specific physiological conditions or an alternative host for stable lysogen establishment [44]. Other authors only predicted the Yua-related phage's temperate nature based on the presence of integrase and repressor in the genome but did not try to check this property, which pertains to phages PAE1 [62], S218 [63] and Ab18, 19 and 20 [64]. Thus, this is the first confirmation that Yua-related siphoviruses can form lysogeny, which is not desirable from the point of view of the application of phages in therapy. Considering that prophages almost always influence the bacterial phenotype, the results of this study clearly indicated a potential role for the B. bronchiseptica LK3 phage in lysogenic conversion [65].

After examining the LK3 lysogenic strains, it was confirmed that sheep blood hemolysis and flagellar motility were elevated, confirming phage involvement in virulence. Similarly, B. bronchiseptica infection with phage LK3 significantly reduced sensitivity to betalactam antibiotics. More importantly, we showed that siphoviruses encode diguanylatecyclase with a GGDEF domain, a key initiator of biofilm formation in bacteria, and we demonstrated hyperbiofilm production in lysogenic bacteria. These data clearly indicate the possible role of siphoviruses in the biofilm formation of B. bronchiseptica, which is thought to support bacterial survival and persistence in the mammalian respiratory tract. The mechanisms of these changes, however, should be further examined, as well as the effect of these phages to better understand the phage contribution to bacterial virulence. Taking into consideration that $B$. bronchiseptica is known to modulate strongly both innate and adaptive immune responses in mammals [66] and that temperate phages can contribute to the attenuation of basic immune defenses such as phagocytosis [67], future studies should also investigate the potential role of siphoviruses in the immunomodulation and pathogenesis of B. bronchiseptica infections [68].

Since the phages are involved in the lysogenic conversion of B. bronchiseptica, their susceptibility to environmental factors was also determined. The phages tolerate a range of $\mathrm{pH}$, high temperatures and concentrations of salt and urea, and the demonstrate the ability to persist even in environments unfavorable to the host bacteria. It is well known that among phages, members of family Siphoviridae possess the most stable virions [69]. Maintenance of infectivity at high temperatures $\left(65^{\circ} \mathrm{C}\right)$ is of great importance, as we have shown here that these phages are involved in bacterial virulence, and pasteurization is not a barrier to their transmission.

\section{Conclusions}

In summary, this is the first evidence of the antibacterial activity of B. bronchiseptica bacteriophages. the first genomic analysis of a B. bronchiseptica-specific phage from the family Siphoviridae and the first confirmation of lysogeny formation by Pseudomonas phage Yua-related bacteriophages. The phages are not appropriate for phage therapy because of their temperate nature despite the high total bacterial growth inhibition and anti-biofilm effect. They affect bacterial biofilm production, hemolytic properties, motility and antibiotic susceptibility, indicating involvement in lysogenic conversion. Furthermore, the phages 
are stable under unfavorable conditions for B. bronchiseptica, so they can persist in the environment and lysogenize new hosts.

Author Contributions: P.K. and A.P.F. conceived the study and designed the main experimental plan. A.P.F., P.K., V.A.S., D.G., Z.D. and G.R. analyzed the data. A.P.F. and P.K. wrote the paper. A.P.F and P.K. performed experiments. P.K. supervised the study. All authors have read and agreed to the published version of the manuscript.

Funding: This work was supported by Ministry of Education, Science and Technological Development of the Republic of Serbia (Grant No. 451-03-68/2020-14/200125), Scientific Fund of Serbiaproject PHANTER and Hungary-Serbia IPA Cross-border Co-operation Programme, project NNAA HUSRB/1203/214/250.

Institutional Review Board Statement: Not applicable.

Informed Consent Statement: Not applicable.

Data Availability Statement: The genomic sequences of the Bordetella bronchiseptica viruses are available in Genbank under the accession numbers KX961385 (LK3), KY000218 (MW2), KY000219 (CN2), KY000220 (FP1) and KY000221 (CN1).

Acknowledgments: The authors acknowledge Nicole Guiso from Institut Pasteur (Paris, France) and Aleksandra Markovic from Veterinary Institute Subotica (Subotica, Serbia) for their kindness and support in providing the B. bronchiseptica strains.

Conflicts of Interest: The authors declare no conflict of interest.

\section{References}

1. Garcia-Cantu, M.C.; Hartmann, F.A.; Brown, C.M.; Darien, B.J. Bordetella bronchiseptica and equine respiratory infections: A review of 30 cases. Equine. Vet. Educ. 2000, 12, 45-50. [CrossRef]

2. Parkhill, J.; Sebaihia, M.; Preston, A.; Murphy, L.D.; Thomson, N.; Harris, D.E.; Holden, M.T.G.; Churcher, C.M.; Bentley, S.D.; Mungall, K.L.; et al. Comparative analysis of the genome sequences of Bordetella pertussis, Bordetella parapertussis and Bordetella bronchiseptica. Nat. Genet. 2003, 35, 32-40. [CrossRef]

3. Deeb, B.J.; Digiacomo, R.F.; Bernard, B.L.; Silbernagel, S.M. Pasteurella-Multocida and Bordetella-Bronchiseptica Infections in Rabbits. J. Clin. Microbiol. 1990, 28, 70-75. [CrossRef] [PubMed]

4. Goodnow, R.A. Biology of Bordetella-Bronchiseptica. Microbiol. Rev. 1980, 44, 722-738. [CrossRef]

5. Kadlec, K.; Wiegand, I.; Kehrenberg, C.; Schwarz, S. Studies on the mechanisms of beta-lactam resistance in Bordetella bronchiseptica. J. Antimicrob. Chemother. 2007, 59, 396-402. [CrossRef] [PubMed]

6. Egberink, H.; Addie, D.; Belak, S.; Boucraut-Baralon, C.; Frymus, T.; Gruffydd-Jones, T.; Hartmann, K.; Hosie, M.J.; Lloret, A.; Lutz, H.; et al. Bordetella bronchiseptica infection in cats. ABCD guidelines on prevention and management. J. Feline Med. Surg. 2009, 11, 610-614. [CrossRef] [PubMed]

7. Viitanen, S.J.; Lappalainen, A.; Rajamaki, M.M. Co-infections with Respiratory Viruses in Dogs with Bacterial Pneumonia. J. Vet. Intern. Med. 2015, 29, 544-551. [CrossRef]

8. Berglof, A.; Norlander, T.; Feinstein, R.; Otori, N.; Stierna, P.; Sandstedt, K. Association of bronchopneumonia with sinusitis due to Bordetella bronchiseptica in an experimental rabbit model. Am. J. Rhinol. 2000, 14, 125-130. [CrossRef]

9. Kumar, S.; Singh, B.R.; Bhardwaj, M.; Singh, V. Occurrence of Bordetella infection in pigs in northern India. Int. J. Microbiol. 2014, 2014, 238575. [CrossRef]

10. Woolfrey, B.F.; Moody, J.A. Human Infections Associated with Bordetella-Bronchiseptica. Clin. Microbiol. Rev. 1991, 4, $243-255$. [CrossRef]

11. Ellis, J.A.; Gow, S.P.; Waldner, C.L.; Shields, S.; Wappel, S.; Bowers, A.; Lacoste, S.; Xu, Z.; Ball, E. Comparative efficacy of intranasal and oral vaccines against Bordetella bronchiseptica in dogs. Vet. J. 2016, 212, 71-77. [CrossRef] [PubMed]

12. Ellis, J.A. How well do vaccines for Bordetella bronchiseptica work in dogs? A critical review of the literature 1977-2014. Vet. J. 2015, 204, 5-16. [CrossRef]

13. Speakman, A.J.; Binns, S.H.; Dawson, S.; Hart, C.A.; Gaskell, R.M. Antimicrobial susceptibility of Bordetella bronchiseptica isolates from cats and a comparison of the agar dilution and E-test methods. Vet. Microbiol. 1997, 54, 63-72. [CrossRef]

14. Pruller, S.; Rensch, U.; Meemken, D.; Kaspar, H.; Kopp, P.A.; Klein, G.; Kehrenberg, C. Antimicrobial Susceptibility of Bordetella bronchiseptica Isolates from Swine and Companion Animals and Detection of Resistance Genes. PLoS ONE 2015, 10, e0135703. [CrossRef]

15. Zhang, Y.; Yang, H.; Guo, L.; Zhao, M.F.; Wang, F.; Song, W.B.; Hua, L.; Wang, L.; Liang, W.; Tang, X.B.A.; et al. Isolation, Antimicrobial Resistance Phenotypes, and Virulence Genes of Bordetella bronchiseptica From Pigs in China, 2018-2020. Front. Vet. Sci. 2021, 8, 672716. [CrossRef] 
16. Cisek, A.A.; Dabrowska, I.; Gregorczyk, K.P.; Wyzewski, Z. Phage Therapy in Bacterial Infections Treatment: One Hundred Years After the Discovery of Bacteriophages. Curr. Microbiol. 2017, 74, 277-283. [CrossRef] [PubMed]

17. Petrovic Fabijan, A.; Lin, R.C.Y.; Ho, J.; Maddocks, S.; Ben Zakour, N.L.; Iredell, J.R.; Westmead Bacteriophage Therapy Team. Safety of bacteriophage therapy in severe Staphylococcus aureus infection. Nat. Microbiol. 2020, 5, 465-472. [CrossRef] [PubMed]

18. Petrovic Fabijan, A.; Khalid, A.; Maddocks, S.; Ho, J.; Gilbey, T.; Sandaradura, I.; Lin, R.C.; Ben Zakour, N.; Venturini, C.; Bowring, B.; et al. Phage therapy for severe bacterial infections: A narrative review. Med. J. Aust. 2020, 212, 279-285. [CrossRef] [PubMed]

19. Knezevic, P.; Hoyle, N.S.; Matsuzaki, S.; Gorski, A. Editorial: Advances in Phage Therapy: Present Challenges and Future Perspectives. Front. Microbiol. 2021, 12, 1390. [CrossRef] [PubMed]

20. Liu, M.S.; Gingery, M.; Doulatov, S.R.; Liu, Y.C.; Hodes, A.; Baker, S.; Davis, P.; Simmonds, M.; Churcher, C.; Mungall, K.; et al. Genomic and genetic analysis of Bordetella bacteriophages encoding reverse transcriptase-mediated tropism-switching cassettes. J. Bacteriol. 2004, 186, 1503-1517. [CrossRef] [PubMed]

21. Chen, Y.B.; Yang, L.; Sun, E.C.; Song, J.Y.; Wu, B. Characterisation of a newly detected bacteriophage infecting Bordetella bronchiseptica in swine. Arch. Virol. 2019, 164, 33-40. [CrossRef] [PubMed]

22. Szymczak, M.; Grygorcewicz, B.; Karczewska-Golec, J.; Decewicz, P.; Pankowski, J.A.; Orszigh-Szturo, H.; Bacal, P.; Dolegowska, B.; Golec, P. Characterization of a Unique Bordetella bronchiseptica vB_BbrP_BB8 Bacteriophage and Its Application as an Antibacterial Agent. Int. J. Mol. Sci. 2020, 21, 1403. [CrossRef]

23. Petrovic, A.; Kostanjsek, R.; Rakhely, G.; Knezevic, P. The First Siphoviridae Family Bacteriophages Infecting Bordetella bronchiseptica Isolated from Environment. Microb. Ecol. 2017, 73, 368-377. [CrossRef]

24. Knezevic, P.K.A.; Adriaenssens, E.M. ICTV Taxonomy History: Vojvodinavirus; ICTV, 2020.

25. Tizolova, A.; Guiso, N.; Guillot, S. Insertion sequences shared by Bordetella species and implications for the biological diagnosis of pertussis syndrome. Eur. J. Clin. Microbiol. Infect. Dis. 2013, 32, 89-96. [CrossRef]

26. Tizolova, A.; Brun, D.; Guiso, N.; Guillot, S. Development of real-time PCR assay for differential detection of Bordetella bronchiseptica and Bordetella parapertussis. Diagn. Microbiol. Infect. Dis. 2014, 78, 347-351. [CrossRef]

27. Sambrook, J.; Russell, D.W. Molecular Cloning: A Laboratory Manual, 3rd ed.; Cold Spring Harbor Laboratory Press: New York, NY, USA, 2001

28. Besemer, J.; Lomsadze, A.; Borodovsky, M. GeneMarkS: A self-training method for prediction of gene starts in microbial genomes. Implications for finding sequence motifs in regulatory regions. Nucleic Acids Res. 2001, 29, 2607-2618. [CrossRef]

29. Altschul, S.F.; Gish, W.; Miller, W.; Myers, E.W.; Lipman, D.J. Basic local alignment search tool. J. Mol. Biol. 1990, 215 , 403-410. [CrossRef]

30. Lowe, T.M.; Chan, P.P. tRNAscan-SE On-line: Integrating search and context for analysis of transfer RNA genes. Nucleic Acids Res. 2016, 44, W54-W57. [CrossRef]

31. Walker, P.J.; Siddell, S.G.; Lefkowitz, E.J.; Mushegian, A.R.; Adriaenssens, E.M.; Dempsey, D.M.; Dutilh, B.E.; Harrach, B.; Harrison, R.L.; Hendrickson, R.C.; et al. Changes to virus taxonomy and the Statutes ratified by the International Committee on Taxonomy of Viruses (2020). Arch. Virol. 2020, 165, 2737-2748. [CrossRef] [PubMed]

32. McLaughlin, M.R. Simple colorimetric microplate test of phage lysis in Salmonella enterica. J. Microbiol. Methods 2007, 69, 394-398. [CrossRef] [PubMed]

33. Knezevic, P.; Petrovic, O. A colorimetric microtiter plate method for assessment of phage effect on Pseudomonas aeruginosa biofilm. J. Microbiol. Methods 2008, 74, 114-118. [CrossRef]

34. Knezevic, P.; Obreht, D.; Curcin, S.; Petrusic, M.; Aleksic, V.; Kostanjsek, R.; Petrovic, O. Phages of Pseudomonas aeruginosa: Response to environmental factors and in vitro ability to inhibit bacterial growth and biofilm formation. J. Appl. Microbiol. 2011, 111, 245-254. [CrossRef]

35. Stepanovic, S.; Vukovic, D.; Dakic, I.; Savic, B.; Svabic-Vlahovic, M. A modified microtiter-plate test for quantification of staphylococcal biofilm formation. J. Microbiol. Methods 2000, 40, 175-179. [CrossRef]

36. Janda, J.M.; Abbott, S.L. Expression of an iron-regulated hemolysin by Edwardsiella tarda. FEMS Microbiol. Lett. 1993, 111, 275-280. [CrossRef]

37. Kearns, D.B. A field guide to bacterial swarming motility. Nat. Rev. Microbiol. 2010, 8, 634-644. [CrossRef] [PubMed]

38. Jain, S.; Chen, J. Attachment and Biofilm formation by various serotypes of salmonella as influenced by cellulose production and thin aggregative fimbriae biosynthesis. J. Food Protect. 2007, 70, 2473-2479. [CrossRef]

39. Rosenberg, I.M. Protein Analysis and Purification: Benchtop Techniques; Springer Science \& Business Media: Berlin, Germany, 2006.

40. Azeredo, J.; Sutherland, I.W. The use of phages for the removal of infectious biofilms. Curr. Pharm. Biotechno. 2008, 9, 261-266. [CrossRef] [PubMed]

41. Harper, D.R.; Enright, M.C. Bacteriophages for the treatment of Pseudomonas aeruginosa infections. J. Appl. Microbiol. 2011, 111, 1-7. [CrossRef]

42. Sutherland, I.W.; Hughes, K.A.; Skillman, L.C.; Tait, K. The interaction of phage and biofilms. FEMS Microbiol. Lett. 2004, 232, 1-6. [CrossRef]

43. Irie, Y.; Mattoo, S.; Yuk, M.H. The Bvg virulence control system regulates biofilm formation in Bordetella bronchiseptica. J. Bacteriol. 2004, 186, 5692-5698. [CrossRef] [PubMed] 
44. Ceyssens, P.J.; Mesyanzhinov, V.; Sykilinda, N.; Briers, Y.; Roucourt, B.; Lavigne, R.; Robben, J.; Domashin, A.; Miroshnikov, K.; Volckaert, G.; et al. The genome and structural Proteome of YuA, a new Pseudomonas aeruginosa phage resembling M6. J. Bacteriol. 2008, 190, 1429-1435. [CrossRef]

45. Davies, E.V.; Winstanley, C.; Fothergill, J.L.; James, C.E. The role of temperate bacteriophages in bacterial infection. Fems Microbiol. Lett. 2016, 363, fnw015. [CrossRef]

46. Karatan, E.; Watnick, P. Signals, Regulatory Networks, and Materials That Build and Break Bacterial Biofilms. Microbiol. Mol. Biol. Rev. 2009, 73, 310. [CrossRef]

47. Conover, M.S.; Mishra, M.; Deora, R. Extracellular DNA Is Essential for Maintaining Bordetella Biofilm Integrity on Abiotic Surfaces and in the Upper Respiratory Tract of Mice. PLoS ONE 2011, 6, e16861. [CrossRef] [PubMed]

48. Abedon, S.T. Phage Evolution and Ecology. Adv. Appl. Microbiol. 2009, 67, 1-45. [CrossRef] [PubMed]

49. Broussard, G.W.; Oldfield, L.M.; Villanueva, V.M.; Lunt, B.L.; Shine, E.E.; Hatfull, G.F. Integration-Dependent Bacteriophage Immunity Provides Insights into the Evolution of Genetic Switches. Mol. Cell 2013, 49, 237-248. [CrossRef] [PubMed]

50. Golding, I. Decision Making in Living Cells: Lessons from a Simple System. Annu. Rev. Biophys. 2011, 40, 63-80. [CrossRef]

51. Amgarten, D.; Martins, L.F.; Lombardi, K.C.; Antunes, L.P.; de Souza, A.P.S.; Nicastro, G.G.; Kitajima, E.W.; Quaggio, R.B.; Upton, C.; Setubal, J.C.; et al. Three novel Pseudomonas phages isolated from composting provide insights into the evolution and diversity of tailed phages. BMC Genom. 2017, 18,1-18. [CrossRef]

52. Bae, H.W.; Chung, I.Y.; Sim, N.; Cho, Y.H. Complete genome sequence of Pseudomonas aeruginosa siphophage MP1412. J. Virol. 2012, 86, 9537. [CrossRef]

53. Casjens, S.R.; Gilcrease, E.B. Determining DNA packaging strategy by analysis of the termini of the chromosomes in tailedbacteriophage virions. Methods Mol. Biol. 2009, 502, 91-111. [CrossRef]

54. Lee, J.; Chastain, P.D., II; Kusakabe, T.; Griffith, J.D.; Richardson, C.C. Coordinated leading and lagging strand DNA synthesis on a minicircular template. Mol. Cell 1998, 1, 1001-1010. [CrossRef]

55. Wallen, J.R.; Majka, J.; Ellenberger, T. Discrete Interactions between Bacteriophage T7 Primase-Helicase and DNA Polymerase Drive the Formation of a Priming Complex Containing Two Copies of DNA Polymerase. Biochemistry-Us 2013, 52, 4026-4036. [CrossRef] [PubMed]

56. Liu, M.; Deora, R.; Doulatov, S.R.; Gingery, M.; Eiserling, F.A.; Preston, A.; Maskell, D.J.; Simons, R.W.; Cotter, P.A.; Parkhill, J.; et al. Reverse transcriptase-mediated tropism switching in Bordetella bacteriophage. Science 2002, 295, 2091-2094. [CrossRef] [PubMed]

57. Camire, R.M.; Bos, M.H.A. The molecular basis of factor V and VIII procofactor activation. J. Thromb. Haemost. 2009, 7, 1951-1961. [CrossRef]

58. Briers, Y.; Walmagh, M.; Lavigne, R. Use of bacteriophage endolysin EL188 and outer membrane permeabilizers against Pseudomonas aeruginosa. J. Appl. Microbiol. 2011, 110, 778-785. [CrossRef] [PubMed]

59. Fernandes, S.; Sao-Jose, C. Enzymes and Mechanisms Employed by Tailed Bacteriophages to Breach the Bacterial Cell Barriers. Viruses 2018, 10, 396. [CrossRef]

60. Lohr, J.E.; Chen, F.; Hill, R.T. Genomic analysis of bacteriophage Phi JL001: Insights into its interaction with a sponge-associated alpha-proteobacterium. Appl. Environ. Microb. 2005, 71, 1598-1609. [CrossRef]

61. Seguritan, V.; Feng, I.W.; Rohwer, F.; Swift, M.; Segall, A.M. Genome sequences of two closely related Vibrio parahaemolyticus phages, VP16T and VP16C. J. Bacteriol. 2003, 185, 6434-6447. [CrossRef]

62. Dyson, Z.A.; Seviour, R.J.; Tucci, J.; Petrovski, S. Genome Sequences of Pseudomonas oryzihabitans Phage POR1 and Pseudomonas aeruginosa Phage PAE1. Microbiol. Resour. Ann. 2016, 4, e01515-15. [CrossRef]

63. Forti, F.; Roach, D.R.; Cafora, M.; Pasini, M.E.; Horner, D.S.; Fiscarelli, E.V.; Rossitto, M.; Cariani, L.; Briani, F.; Debarbieux, L.; et al Design of a Broad-Range Bacteriophage Cocktail That Reduces Pseudomonas aeruginosa Biofilms and Treats Acute Infections in Two Animal Models. Antimicrob. Agents Chemother. 2018, 62, e02573-17. [CrossRef]

64. Essoh, C.; Latino, L.; Midoux, C.; Blouin, Y.; Loukou, G.; Nguetta, S.P.A.; Lathro, S.; Cablanmian, A.; Kouassi, A.K.; Vergnaud, G.; et al. Investigation of a Large Collection of Pseudomonas aeruginosa Bacteriophages Collected from a Single Environmental Source in Abidjan, Cote d'Ivoire. PLoS ONE 2015, 10, e0130548. [CrossRef]

65. Fortier, L.C.; Sekulovic, O. Importance of prophages to evolution and virulence of bacterial pathogens. Virulence 2013, 4, 354-365. [CrossRef] [PubMed]

66. Gestal, M.C.; Howard, L.K.; Dewan, K.; Johnson, H.M.; Barbier, M.; Bryant, C.; Soumana, I.H.; Rivera, I.; Linz, B.; Blas-Machado, U.; et al. Enhancement of immune response against Bordetella spp. by disrupting immunomodulation. Sci. Rep. 2019, 9, 20261. [CrossRef]

67. Cieslik, M.; Baginska, N.; Jonczyk-Matysiak, E.; Wegrzyn, A.; Wegrzyn, G.; Gorski, A. Temperate Bacteriophages-The Powerful Indirect Modulators of Eukaryotic Cells and Immune Functions. Viruses 2021, 13, 1013. [CrossRef] [PubMed]

68. Cattelan, N.; Dubey, P.; Arnal, L.; Yantorno, O.M.; Deora, R. Bordetella biofilms: A lifestyle leading to persistent infections. Pathog. Dis. 2016, 74, ftv108. [CrossRef]

69. Jonczyk, E.; Klak, M.; Miedzybrodzki, R.; Gorski, A. The influence of external factors on bacteriophages-Review. Folia Microbiol. (Praha) 2011, 56, 191-200. [CrossRef] [PubMed] 